\title{
Ecological and Economic Advantages of Using Polypropylene Tree Shelters in Lowland Oak Forests
}

\author{
Boris Liović ${ }^{1 \rrbracket}$, Željko Tomašić ${ }^{2}$, Igor Stankić ${ }^{3}$
}

\author{
${ }^{1}$ Croatian Forest Research Institute, Cvjetno naselje 41, 10450 Jastrebarsko, Croatia \\ ${ }^{2}$ Croatian Forests Ltd., Ljudevita Farkaša Vukotinovića 2, 10000 Zagreb, Croatia \\ 3 University of Zagreb, Faculty of Forestry, Svetošimunska 25, 10002 Zagreb, Croatia \\ $\varangle$ Corresponding author: e-mail: boris|@sumins.hr
}

Citation:

LIOVIĆ B, TOMAŠIĆ Ž, STANKIĆ I 2013 Ecological and Economic Advantages of Using Polypropylene Tree Shelters in Lowland Oak Forests. South-East Eur For 4 (2): 115-125

\begin{abstract}
Background and Purpose: The process of joining the market competition by the company "Croatian Forests", managing state forests in Croatia, is related to the transformation of the company into a trading company. This means that beside the biological and ecological goals in managing forests, the special attention is to be paid to business operations with the highest economic outputs, reduced costs and increased income. In order to enhance the regeneration of pedunculate oak forests in present day changing ecological and challenging economic conditions, as our proposal, is implementation of one of the artificial methods of regeneration pedunculate oak forests by planting seedlings protected with polypropylene tree shelters.
\end{abstract}

Materials and Methods: The paper deal with existing knowledge about the conditions and characteristics of two methods of oak stand regeneration and analyzed data of current norms, standards and prices for each of these methods. The analysis compared the two methods: method of regeneration with unprotected seedlings, and seedlings protected with polypropylene tree shelters.

Results and Conclusions: The research results showed that in comparison to the common seedling planting method, this method of pedunculate oak stand regeneration on difficult terrains with complex stand conditions is ecologically and economically more beneficial.

Keywords: forest stands regeneration, polypropylene tree shelters, ecological and economic advantages

\section{INTRODUCTION}

Two words that are now often used in forestry, as a positive conservative branch of the economy, are ecology and economics (the latter term actually means relating to forestry under the rules and laws of competition). The process of "ecologization" of Forestry is 
emphasized by the certification of forests, which imposes a rather demanding standard in the application of pesticides, and requires, instead of environmentally harmful chemical protection of forests, the use of integrated mechanical, biological, biotechnological and other environmentally friendly materials and measures to protect forest ecosystems. Further process acceleration is gained through rising public awareness about the need for sustainable development and the protection of biodiversity and nature.

The process of joining the market competition by the company Croatian Forests Ltd., managing state forests in Croatia, is related to the transformation of the company into a trading company. This means that beside the biological and ecological goals in managing forests, special attention is to be paid to business operations with the highest economic outputs, reduced costs and increased income.

At the first glance it seems that these two terms are incompatible, that is, that the ecologically acceptable protection measures raise the price of the final product, making it thus less competitive on the market. That this is not the case is evident on the example of polypropylene tree shelters.

Polypropylene shelters were introduced by the English forester, Graham Tuley, in 1979. The shelters are pipes made of two-layered polypropylene in various light color tones (Figure 1).

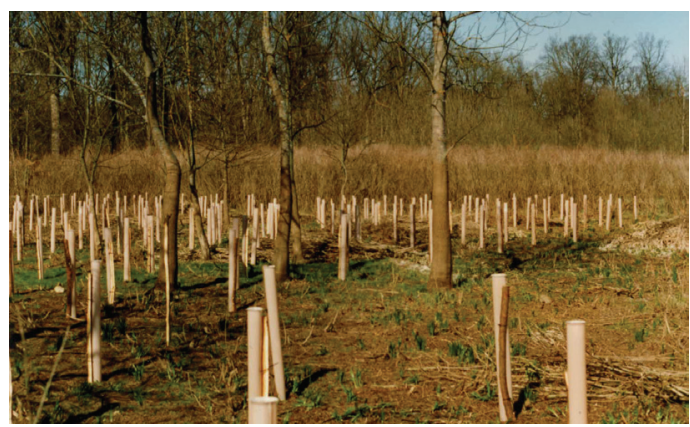

FIGURE 1. An experimental plot with polypropylene tree shelters (Forest Office Kutina, Kutina Lowland Forests management unit, June 1996)
Polypropylene, unlike the polyvinylchloride (PVC), the material also used to produce plastics, has several important advantages in the sense of ecological acceptability:

- during manufacturing (unlike PVC) no dioxins are neither created, nor released, which are among the most poisonous chemicals known today. They are carcenogenous and disturb the immunological and hormonal systems.

- polypropylene, unlike the PVC compounds, does not contain phthalates, very damaging additives that increase the PVC elasticity and disturb hormonal functions.

- when burning polypropylene no dioxins or any other poisonous compounds are created, and no additives are released on dump sites that may contaminate drinking water sources, which is a significant problem with PVC.

The upper rim of the shelter is slightly bent towards outside to avoid damaging the plants after they outgrow the shelter. Due to the more economical and easier transport and storing, the shelters are 5 in a package, one in the another, so that their diameters are between 8.3 and $10.8 \mathrm{~cm}$. They are manufactured as 0.2 $\mathrm{m}$ in height due to the protection of rodents and up to $1.8 \mathrm{~m}$ against wildlife (deer). The shelter is placed next to the pole and fastened with two plastic ties.

The first shelters were sensitive to UV rays and atmospheric influences and fell apart in two to three years after planting (Figure 2).

The improved shelters with the UV ray inhibitors may last for up to 8 years and are capable to provide support to thin and long trunks even after the trees outgrow the shelters. Without support the trees would bend and be covered by weeds. The technology of producing shelters was improved in 1990 by introducing the weakening line along the shelter's length because previously they lasted for too long and stayed on the tree for 10 and more years (Figure 3 ). The line consists of holes along the shelter that allow the shelter to rip when the tree outgrows the shelter's diameter. 


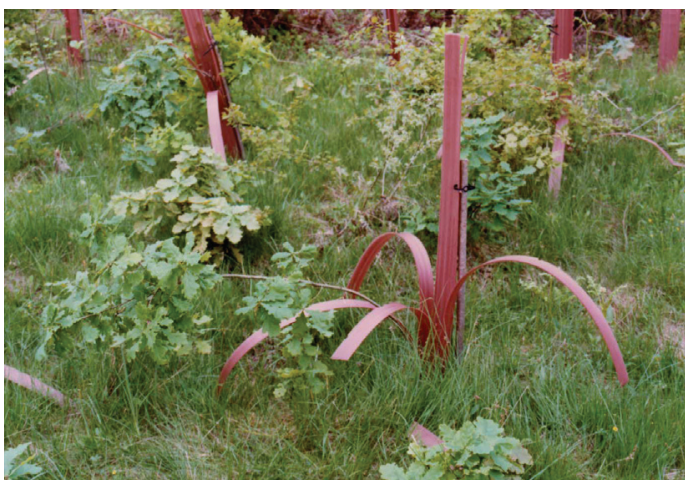

FIGURE 2. An inadequate structure and composition of the shelter causing their premature deterioration (September 2002)

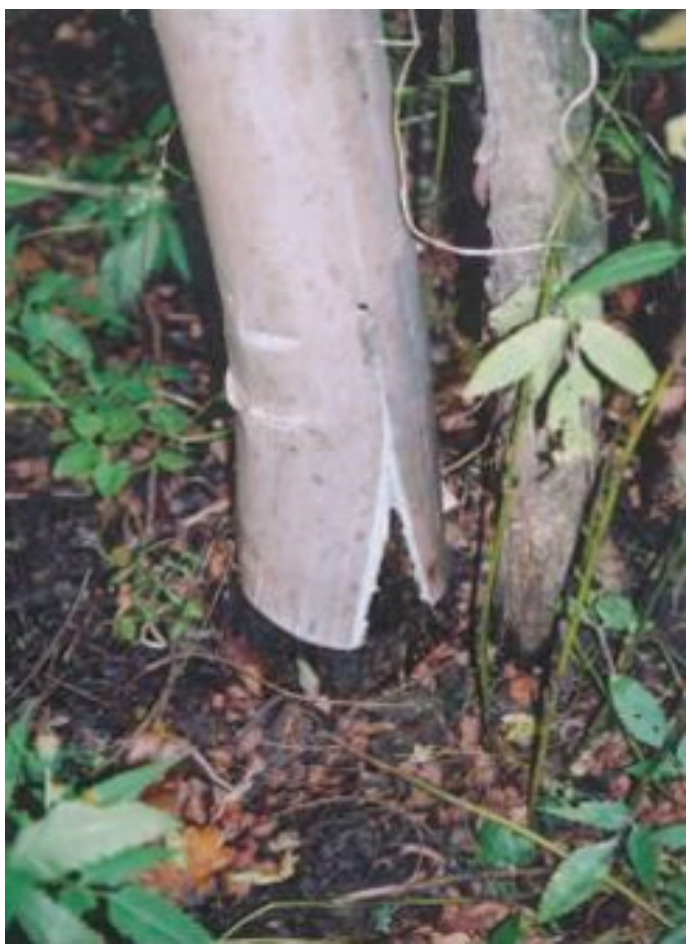

FIGURE 3. A polypropylene tree shelter without a weakening line (August 2006)

The basic advantage of shelters is an accelerated growth of seedlings, as reported by many authors [1-6]. Liović [5] conducted the research on experimental plot near Kutina and found that six vegetation periods after the planting the medium height of the pedunculate oak (Quercus robur L.) seedlings was over $200 \mathrm{~cm}$, while the heights of the unprotected seedlings was about $50 \mathrm{~cm}$. Some protected seedlings grew up to the height of $4 \mathrm{~m}$. Jeffrey and Stephens [7] reported that the wildlife gnawing on the unprotected seedlings of the black walnut (Juglans nigra L.) at the beginning of the planting was higher $(34.0 \mathrm{~cm})$ than three years later $(28.2$ $\mathrm{cm})$ while the protected seedlings grew from $36.1 \mathrm{~cm}$ to $89.0 \mathrm{~cm}$. The red oak (Quercus rubra L.) seedlings in shelters grew from 30.2 $\mathrm{cm}$ during three vegetations to $110.6 \mathrm{~cm}$, while the control (unprotected) grew from the initial $31.1 \mathrm{~cm}$ only to $45.1 \mathrm{~cm}$.

Liović [5] reported the increased growth and the lower mortality of protected seedlings, so that the mortality rate of sheltered seedlings after four vegetations was $6 \%$, while it was $24 \%$ in unprotected seedlings. Jeffrey and Stephens [7] also reported the mortality of the seedlings protected by polypropylene shelters was significantly lower than in the control group. During three vegetation $8 \%$ of the unprotected red oak seedlings withered, while only $2 \%$ of the protected seedlings died. The same experiment reported the $8 \%$ death of the unprotected black oak (Quercus kelloggii Newb.) seedlings, while all the protected seedlings survived. Placing the shelters in the shadow of old trees did not increase the survival of seedlings so this method of regeneration should be avoided [8]. Generally, the assistance (help) of polypropylene shelters would not be required at all if the regeneration cuttings on the entire oak forest areas in Croatia would be done successfully.

The deterioration of forests is a process that is especially frequently present in the lowland pedunculate oak forests. The increased intensity of forest decline lowers the number of young oak trees [9]. The areas with forest deterioration symptoms are increasing, so we may expect that the areas for artificial regeneration by planting seedlings or sowing acorns will keep increasing. The ever more frequent lack of acorns and/or the reduced acorn yields lately, improperly 
done regeneration cuttings and artificial regeneration by pedunculate oak seedlings, the flooding of forest areas, as well as other causes that often lead to increased weediness or turning areas intended for regeneration into marshes, make the artificial and natural regeneration more difficult and prevents natural regeneration. Artificial regeneration is more expensive than natural regeneration (this obligation is not questionable in normal conditions) so failure is not acceptable because the regeneration process would have to be repeated several times in some cases.

The newly founded clonal seed orchard of pedunculate oak trees will produce seeds that will have to be rationally handled due to their limited quantities. There are three clonal seed orchard in Croatia, with 119 clones on 103 ha [10]. Plant shelters offer the opportunity to regenerate forests artificially with seedlings from this seed and with the least loss. The most detrimental factors that decrease the survival of oak seedlings are weeds, powdery mildew (Microsphaera alphitoides Grif. et Maubl.) disease and wildlife. Thick weeds overgrow the seedlings fast, shadows them, reduce the intensity of photosynthesis and, at the same time, the lower vitality and the growth of the plants. Besides, weeds are seedlings' competition for water and nutrients. In winter, the dead over ground parts of weeds mechanically press and bend young oak trees. Kozarac [11] wrote about the detrimental influence of weeds in regenerating oak forests, because the condition of weeding gives a greater advantage to ash (Fraxinus angustifolia Vahl). Plant disease, powdery mildew, reduces the intensity of photosynthesis and wildlife bites off seedling tops which influences growth. The growth within the shelters shortens the time the plant spends in the weed competition zone, and the plant is not exposed to powdery mildew, wildlife and rodents in its most sensitive phase of development, and has a much larger probability of survival, as mentioned above. These are the reasons that in areas where natural regeneration failed and there are several negative factors preventing or burdening artificial regeneration, polypropylene shelters may be a good choice. The justification of such ideas may be supported by an example from German forestry quoted by Hammer [12]. He described how the problem of deforestation was successfully solved by planting seedlings protected by polypropylene shelters after the catastrophic consequences of the hurricane "Lothar" in the vicinity of Baden-Baden in the Schwartzwald area. The influence of the hurricane was recorded on more than 2,000 ha of forests. In order to resolve the problem, 350,000 polypropylene shelters were purchased to plant some 20 species of trees ( $49 \%$ of deciduous trees: oak, ash, wild fruit trees, etc.). Besides the planted 350,000 plants protected by polypropylene shelters (1 to 2 year seedlings), the area between the planted trees was left to regenerate to low vegetation left after the hurricane. Some plants were planted under the shade of undamaged trees. The author reported that today these are vital young stands created by a combined natural and artificial regeneration, and the "exceptionally high percentage of seedling survival if protected with polypropylene shelters". Hammer [12] also emphasized the advantages of planting seedlings in polypropylene shelters: smaller seedlings may be planted because they quickly outgrow the shelters and their roots develop better than large seedlings that are used to avoid the competitive high weeds (also more expensive). The economic advantages include a smaller number of seedlings, less manpower to plant the seedlings and no requirements for fences to protect against wildlife. As ecological advantage, Hammer [12] reported, that chemical as well as other forms of tending after two years are virtually unnecessary.

The purpose of this research is to determine the advantages of using polypropylene shelters for the protection of planted trees in artificial regeneration and/or founding new pedunculate oak stands in relation to using the common artificial regeneration method and planting unprotected seedlings, especially the 
advantages determinable through ecological and economical indicators of the applied methods.

\section{MATERIALS AND METHODS}

The research of the comparative elements included the cost analysis of all important actions, as well as costs of seedlings and other materials for regeneration and tending of pedunculate oak stands up to 5 years in case the stand is set on the weeded area without natural offspring. These costs depend on the applied regeneration method.

The research used the comparative method of evaluation the ecological and economic advantages, that is, the efficiency of the regeneration and tending of oak forest stands with the two methods applied. The common method of planting and tending of 10,000 pedunculate oak seedlings $2+0$ per 1 ha, with the previous preparation of the entire site by filling up with seedlings $3+0 \mathrm{~A}$ and tending of young plants up to 5 years, was compared to the regeneration by polypropylene shelters and tending of young stands up to same age. It may be assumed that the regeneration method of applying polypropylene shelters will show certain advantages in relation to the common method (in the ecological and economical sense) because a significantly lesser number of seedlings is planted, the area for tending to young trees is smaller (financial cost, the necessary quantities of chemical compounds for tending and protection of young trees, etc.), and if necessary, the possibility is open to apply mechanical means for tending and regeneration.

The normative data of the preparatory silvicultural plan for the year 2011 (the IT package of the HS PPU software), plus the control methods of oak stand cultivation for Forest Administration Vinkovci and Forest Administration Zagreb was used for the comparison of work cost and material used with the common method of regenerating pedunculate oak stands.
The data for the elements of the pedunculate oak stand regeneration by applying polypropylene shelters was partially used from the same program package, and partially recorded as separate normative, due to the specificity of the method.

Besides determining the quantity of the applied (detrimental) chemical means (chemical tending, protection against powdery mildew, rodents) for the purposes of comparing the ecological advantages of the aforementioned methods, based on the appropriate norms and standards, as well as the planned prices for 2011, the important economical indicators of the regeneration and tending costs per 1 ha were to be determined.

The earlier research conducted by Liović and Ocvirek [4] showed that, due to the specific microclimate within the shelter, the plant disease powdery mildew on oak seedlings may be disregarded, while the unprotected seedlings were heavily damaged (it is necessary to protect the seedlings against powdery mildew). Liović [13] also quoted the results of another research when he determined that $15 \%$ of the control group of unprotected plants were eaten by wood wasps (Apethymus abdominalis Lep.), while the seedlings protected by shelters remained undamaged. The results of both research indicate that the use of fungicides and insecticides for these purposes may be significantly reduced or completely excluded if pedunculate oak seedlings are regenerated by applying polypropylene shelters.

\section{RESULTS AND DISCUSSION}

\section{Site Preparation}

The costs of preparing the sites on open surfaces intended for pedunculate oak stand regeneration were higher with a common method of regeneration because mechanical and chemical preparation of the site is done on the entire area, while with the use of polypropylene shelters the unwanted plants were removed chemically only in the row 
where the seedlings protected with shelters were to be planted. The required quantity of chemicals for this purpose (the glyphosate herbicide) with the common method of regeneration was 101/ha, with machinery (tractor + atomizer), while the regeneration with polypropylene shelters only required 2 to 2.5 I of herbicide per 1 ha, using a portable nozzle or a smaller atomizer. The otherwise ecologically suitable herbicide with glyphosate as active ingredient became a large threat to the biological diversity. Namely, the application of total herbicide kills almost all plant organisms on the treated surface, both the frequent, but also those rare plant species that would hardly "return" to that area.

The presentation of costs when applying the two methods on Figure 5 shows the relations of compared cost variables indicating the advantages, that is, the acceptability in the economic and ecological sense.

\section{Protection of Seedlings from Wildlife and Rodents}

Setting up protective fences against wildlife and protective measures against rodents when applying the method of regeneration by using polypropylene shelters were not necessary, while the common method of regeneration almost always required the aforementioned measures to protect young stands (the total cost of $822.53 € / h a)$. Besides the financial benefit, the ecological advantage of this method was also important due to the left-out dangerous pesticides, which reduced the population of pest, but also negatively influenced all other animal species and presented a danger of soil infiltration and further detrimental influences.

\section{Planting Seedlings and Filling}

Although the unit price of an oak seedling planted in a polypropylene shelter (planting the seeding, purchasing, transport and setting of the polypropylene shelter and the supporting pole $=3.51 €$ per seedling) was significantly higher than the oak seedling planed with a common method of regeneration (planting
- $0.66 €$ per seedling + filling $0.96 €$ per seedling), the total calculation, due to 7 times less required quantity of seedlings, shows that the planting by using the polypropylene shelters was economically significantly more beneficial:

a) common method:

planting seedlings -10.000 pcs $2+O B$

$=6,566.70 € /$ ha

+ filling -5.000 pcs $3+0$ A (to $10 \%$ surface)

$=477.81 € / \mathrm{ha}$

Total: planting + filling

$=7,044.51 \mathrm{€} / \mathrm{ha}$

b) planting with polypropylene shelters (1.500 pcs. $2+0 \mathrm{~B})=5,259.55 € /$ ha

Due to the potential application of mechanization in protecting and tending, it was more beneficial to plant seedlings in rows, but they may be planted on the prepared area in no order with a certain distance in between to preserve the naturally regenerated forest appearance.

There may be an objection that a relatively small number of seedlings (up to 1500/ha) does not ensure a sufficient diversity. The fact is that larger areas are being regenerated so that the diversity is present on such a large area. Also, the selection of trees in tending, cleaning and thinning is done so that tall and straight trees are chosen (technically, the most perspective trees), so in that way, the selected trees in the natural regeneration do not completely represent a wide biological diversity within the species

\section{Tending of Seedlings up to 5 Years}

Due to the great growth and easy visibility of polypropylene shelters and protected plants, the tending of seedlings is significantly easier. With the common method of regeneration chemical tending includes the tractor atomizer with a norm of 0.17 working days per 1 ha and the 2.5 I of herbicide, meaning the total of $63.07 € / h a$, unlike the polypropylene shelter method that spends the total of $49.43 € /$ ha with a portable nozzle in the area of $1 \mathrm{~m}$ around each shelter 2 to 3 years after planting. It is important to mention that the herbicides are applied by a portable nozzle and not by heavy machinery that stiffens the soil and often the access to the tending area 
is difficult. Hand mechanical tending with the common method of regeneration consists of the working norm of 10 workers day per 1 ha, which means with additional cost of tools the total of $666.49 € /$ ha, while the polypropylene shelter method requires 2 workers per 1 ha for hand tending and the cost of $132.43 € /$ ha. The fact is also that it will be increasingly more difficult to ensure a larger number of workers for this job and low pay in the future. The total difference in costs of tending seedlings is, therefore, $484.63 € /$ ha in favor of the polypropylene shelter regeneration method, which is the economic advantage of this method.

It should be also mentioned that on the basis of the experience of applying polypropylene shelters in Croatia for the purposes of assisted regeneration (the first research began some twenty years ago), that tending and cleaning, otherwise done in turn until the oak stands are 20 years old, is almost unnecessary (Figure 4).

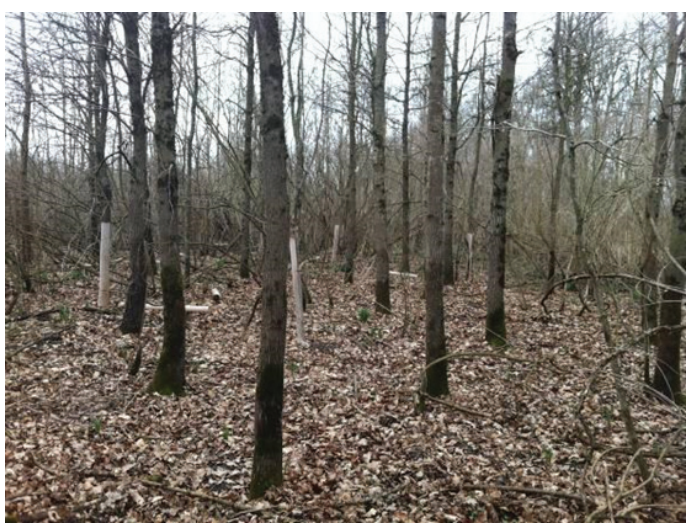

FIGURE 4. An experimental plot of the pedunculate oak forest stand regenerated 18 years ago by polypropylene tree shelters in the Kutina Lowland Forest management unit (Forest Office Kutina,30 March 2012)

\section{Protecting Plants from Disease and Pests}

The data on normative costs of protecting seedlings against plant diseases and pests it is evident that the cost per 1 ha for this purpose (fungicides + insecticides, without airborne treatments) is $333.31 € /$ ha, when the common regeneration method is used, while the application of the method with polypropylene shelters means no such financial cost, but also the cost of pesticides is low and rare. This fact also indicates the economic and ecological advantage of regenerating pedunculate oak stands with polypropylene shelters.

\section{The Total Cost of Pedunculate Oak Stand Regeneration Depending on the Applied Method}

Summing up all costs that include pedunculate oak tree stand regeneration on clean areas, as well as the tending of the young stands in the first five years (Figure $5)$, it is evident that the cost of the common method of regenerating pedunculate oak tree seedlings is the total of 9,697.74 $€ /$ ha, while the total cost for the same purpose when applying the polypropylene shelters is $6,160.21 € / h a$, meaning the total difference of $3,537.53 € /$ ha less per 1 ha. Except this method being financially (economically) more beneficial by $36 \%$, the success rate of regeneration with this method is very high (survival of seedlings) in relation to the common method $[6,14]$.

Similarly, the ecological advantages of this method should be emphasized, as determined through significantly reduced quantities of the required chemicals, whether herbicides, fungicides and/or insecticides, whose detrimental impact to the ecosystem, environment and health of people is difficult to evaluate, especially in financial terms.

\section{Potential Applications of Polypropylene Tree Shelters to Protect Seedlings}

1. Reforestation of weeded clearings or low bush plants (e.g. Amorpha fruticosa L., Carex sp., Cornus sanguinea L., etc.), with the terrain configuration that does not allow the application of technical equipment and the areas endangered by wildlife 


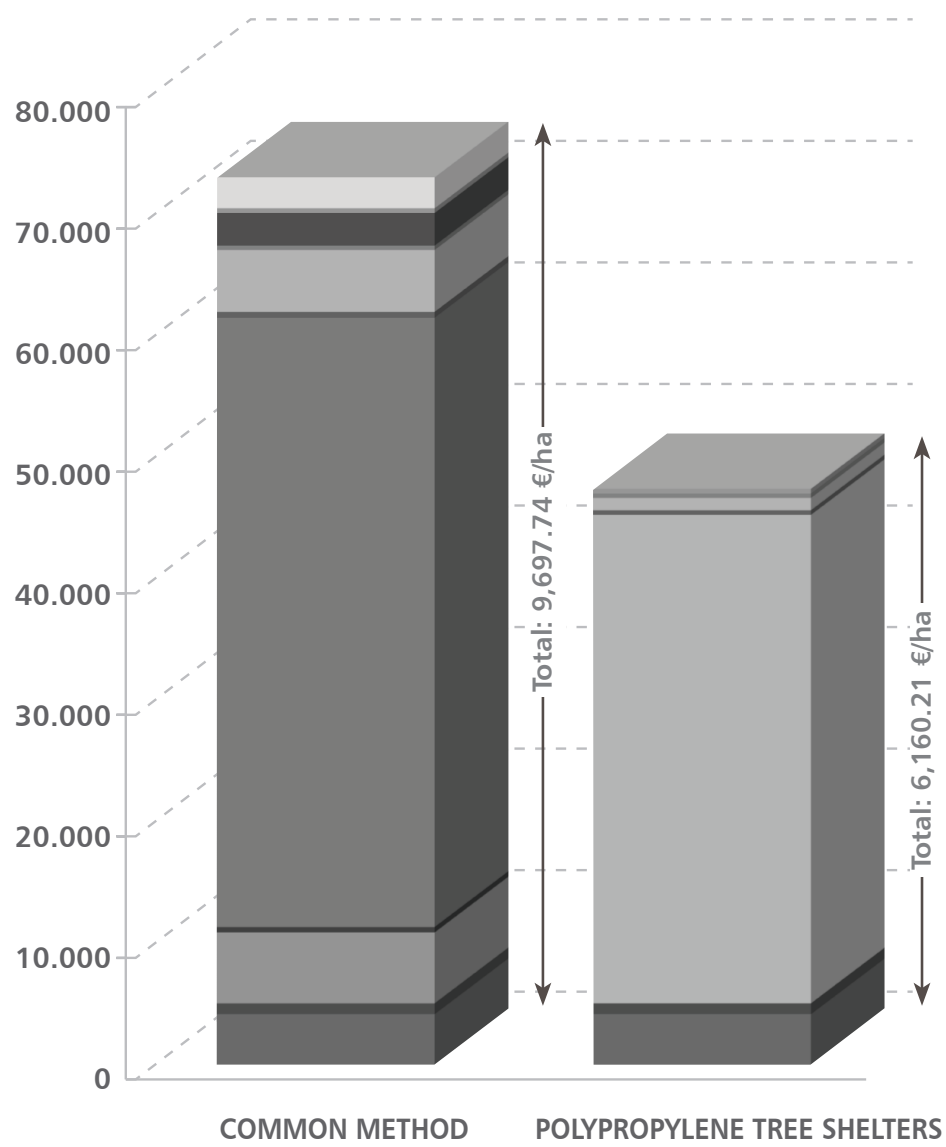

FIGURE 5. Comparison of the cost structure - cost per 1 ha in $€$ of the pedunculate oak stand regeneration of the common method and with the help of the polypropylene tree shelter (middle rate published by the Croatian

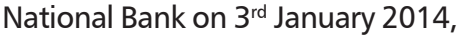
$1 €=7.626505$ HRK)

Site preparation - manually, habitually: $552.94 € /$ ha; with polypropylene tree shelters: $552.94 € /$ ha

Site preparation - mechanized, habitually: $117.22 € /$ ha; with polypropylene tree shelters: $68.18 € /$ ha

Installing of protection fence, habitually: $763.65 € /$ ha; with polypropylene tree shelters: $0 € /$ ha

Rodent protection, habitually: $58.87 € /$ ha; with polypropylene tree shelters: $0 € /$ ha

Supply, transport, planting and seedlings manipulation (10.000 pieces/ha seedlings of Querscus robur $2+0 \mathrm{~B})$ habitually: $6,566.70 € / \mathrm{ha}$; with polypropylene tree shelters: $0 € / \mathrm{ha}$

- "Supply, transport, and seedlings planting; Supply, transport, and setting of stakes (1500 pieces per hectare) (1.500 pieces/ha seedlings of $Q R 2+0 B)$, habitually: $0 € /$ ha; with polypropylene tree shelters: $5,259.55 € /$ ha"

Tending of young plants (applying of herbicides), habitually: $63.07 € /$ ha; with polypropylene tree shelters: $49.43 € / h a$

Tending of young plants (manually), habitually: $666.49 € /$ ha; with polypropylene tree shelters: $132.43 € / h a$

Establishing of silvicultural breaks (forestry mulcher 1,5 m), habitually: $47.33 € /$ ha; with polyp. tree shelters: $47.33 € /$ ha

Filling-up with 5.000 seedlings/ha 3+0 A, habitually: $477.81 € /$ ha; with polypropylene tree shelters $0 € /$ ha Maintaining of silvicultural breaks (forestry mulcher $1,5 \mathrm{~m}$ ), habitually: $50.35 € /$ ha; with pol. tree shelters: $50.35 € /$ ha

Protection from plant deseases, habitually: $333.31 € /$ ha; with polypropylene tree shelters: $0 € /$ ha 
With selected seedlings of economic species (phenotype, genotype) and no more than 1500 $\mathrm{pcs} / \mathrm{ha}$ protected with polypropylene shelters, it is possible to regenerate such areas primarily due to the accelerated height growth of protected plants. This enables the planting of other species of the same phytocenosis at the same time, without protection and not more than $1000 \mathrm{pcs} / \mathrm{ha}$.

For oak and ash stands it may be done in the way of planting seedlings in rows $2.5 \mathrm{~m}$ distant with $4.0 \mathrm{~m}$ between the seedlings, provided that every other row is planted by oak and ash alternatively. In the rows between the protected seedlings it is advisable to plant a certain number of currently financially more valuable species (e.g. wild cherry - Prunus avium L., checker tree Sorbus torminalis L., etc). Naturally, should the stand conditions allow that.

\section{Assistance to Regeneration}

In the areas already regenerated (with seedlings), with young trees and especially endangered by wildlife teeth, or parts of areas (generally micro depressions) where young ash trees endanger oak trees, it is possible to use protection assisted by polypropylene shelters to obtain quality mixed stands.

\section{Improving the Stand's Quality}

The poorly regenerated stands in the sapling phase may be significantly improved in the biological and financial quality by introducing seedlings of faster growing trees (e.g. ash, wild cherry, black walnut, oak, etc) protected by polypropylene shelters. Pure black locust (Robinia pseudoacacia L.) stands of up to 15 years may be transformed into significantly more valuable mixed stands of oak, wild cherry and black locust stands without waiting for the end of pollination and by using protective pipes.

4. Raising Clonal Seed Orchards - grafts protection

\section{Application in Nursery Production}

6. Protection of the Existing Young Plants

7. Forest Renovation by Seeds from Clonal Seed Orchards, with the Highest Exploitation Rate

\section{CONCLUSIONS}

Based on the research results, it was determined that the method of artificial stand regeneration by using polypropylene shelters is environmentally more beneficial than the method of planting unprotected seedlings (the common method), because instead of preparing the site by spraying the vegetation with herbicides on the entire area, it requires the spraying of stripes of only about $1 \mathrm{~m}$ wide.

Similarly, the use of shelters in tending young plants does not exclude the use of herbicides up to two years after planting, but they are used in significantly lesser quantities, because the entire area is not sprayed, but only a $1 \mathrm{~m}$ diameter circle around each shelter. Besides the financial benefits, this is also the ecologically better method to prepare the site, for regeneration and tending, because the quantities of herbicides are reduced and a larger area is left intact to preserve biodiversity of the future stand (wild fruit trees and other species that do not endanger the pedunculate oaks).

It bears repeating that this is the regeneration on the weeded area without young trees, that is, the area where for certain reasons the natural regeneration of oak stands is not possible.

The presented method of pedunculate oak stand regeneration by using measures to protect the seedlings against competitive weeds, wildlife, plant diseases and pests, is not to be taken as a replacement for the natural regeneration of pedunculate oak stands. This method of artificial regeneration is recommended primarily for the terrains where natural regeneration is not possible by the well-known principles of forest nursing due to various reasons (the calamities damaging the vitality of the forest stand that, in some more difficult cases, may cause their deterioration, flooded terrains at times after the final cutting, the failed natural regeneration and weediness of the entire terrain with problematic weeds and so on). Similarly, although such a method of forest stand regeneration may be objected to be copied from fruit tree nursing and is not common for the nursing methods in Croatian forestry, we 
have to mention that this method has been successfully used for a long time in the forestry of many countries with developed forestry as an economic branch. The negative climatic changes and the results of their influence on ecosystems that seriously change the ecological and stand conditions in forest stands, as well as the changed economic circumstances, lead to the necessity of different ways of thinking, that is, the application of new solutions and technologies in order to overcome the consequences of these events that are inevitable today. In this sense, such thinking is reasonable when considering the ways and possibilities of overcoming the negative consequences of the changed ecological and economic conditions, as one more recent research on this issue confirms the aforementioned claims: "...to take into consideration that many norms, rules, regulations, expertise, tradition, work dynamics and the usual economic actions, that used to be applicable in managing pedunculate oak forests in normal conditions, should be adjusted to the actual stand, structural and site conditions" [15].

\section{REFERENCES}

1. BAINBRIDGE D A 1991 Successful tree establishment on difficult dry sites. In: Proceedings of Third International Windbreaks and Agroforestry Symposium, Ridgetown, ON, Canada. Ridgetown College, Canada, pp 78-81

2. TULEY G1985 The Growth of Young Oak Trees in Shelters. Forestry 58 (2): 181-194. DOI: http://dx.doi.org/10.1093/forestry/58.2.181

3. POTTER M 1988 Treeshelters improve survival and increases early growth rates. J Forest 86 (8): 39-41

4. LIOVIĆ B, OCVIREK M 1997 Plastic treeshelters in the conception of integral forest seedling protection (in Croatian with English summary). Radovi - Šumar inst Jastrebar 32 (1): 31-42

5. LIOVIĆ B 2001 Results of application of polypropylene shelters for the protection of common oak seedlings - six-year experiment (in Croatian with English summary). In: Matić $S$, Krpan A P B, Gračan J (eds) Science in Sustainable Management of Croatian Forests. Faculty of Forestry Zagreb; Croatian Forest Research Institute, Zagreb, pp 309-317

6. LANTAGNE D O 1995 Effects of Tree Shelters on Planted Red Oaks After Six Growing Seasons. In: Gottschalk K W, Fosbroke S L C (eds) Proceedings of the $10^{\text {th }}$ Central hardwood forest conference, Morgentown, WV, USA, 5-8 March 1995. Division of Forestry, West Virginia University; Northeastern Forest Experiment Station, USDA Forest Service, USA, pp 515-522

7. JEFFREY $S$ W, STEPHENS G R 1995 Protection of Tree Seedlings from Deer Browsing. In: Gottschalk K W, Fosbroke S L C (eds) Proceedings of the $10^{\text {th }}$ Central hardwood forest conference, Morgentown, WV, USA, 5-8 March 1995. Division of Forestry, West Virginia University; Northeastern Forest Experiment Station, USDA Forest Service, USA, pp 507-514

8. SCHULER M T, MILLER W G 1995 Shelterwood Treatments Fail to Establish Oak Reproduction on Mesic Forest Sites in West Virginia - Ten Years Result. In: Gottschalk K W, Fosbroke S L C (eds) Proceedings of the $10^{\text {th }}$ Central hardwood forest conference, Morgentown, WV, USA, 5-8 March 1995. Division of Forestry, West Virginia University; Northeastern Forest Experiment Station, USDA Forest Service, USA, pp 375-387

9. MATIĆ S 1994 Number of Plants and the Amount of Seed in Relationship to the Results of Regeneration and Afforestation (in Croatian with English summary). Sumar list 118 (3-4): 71-79

10. GRAČAN J 2003 Seed Stands and Clonal Seed Orchards of Pedunculate Oak (in Croatian with English summary). In: Klepac D, Čorkalo Jemrić K (eds) A Retrospective and Perspective of Managing Forests of Pedunculate Oak in Croatia, Vinkovci, Croatia, 8-9 November 2002. Croatian Academy of Sciences and Arts, The Center for Scientific Work in Vinkovci, Zagreb, Vinkovci, Croatia, pp 185-203

11. KOZARAC J $1886 \mathrm{~K}$ pitanju pomlađivanja posavskih hrastika. Sumar list 10 (2): 50-57; 6: 241-249

12. HAMMER A 2012 Wuchshüllen - Zeitungsartikel, Holzzentralblatt. 22: $578 p$

13. LIOVIĆ B 1993 Protection of Forest Tree Seedlings by Polypropylene Shelters. Radovi - Šumar inst Jastrebar 28 (1-2): 255-262 
14. PONDER JR F 1991 Growth of Black Walnut Seedings Protected by Treeshelters. Annual Report Northern Nut Growers Assotiation 82: 170-174

15. MATIĆ S 2009 Managing Forests of Pedunculate Oak (Quercus robur L.) in Changed Site and Structural Conditions (in Croatian with English summary). In: Matić S, Anić I (eds) Forests of Pedunculate Oak in Changed Site and Management Conditions, Zagreb, Croatia, 24-25 September 2008. Croatian Academy of Sciences and Arts, The Center for Scientific Work in Vinkovci, Zagreb, Croatia, pp 1-22 